\title{
Recent Books and Journals in Public Opinion, Survey Methods, and Survey Statistics
}

Mario Callegaro*

Tags: survey practice

\section{Survey Practice}

Vol. 4, Issue 2, 2011

Recent Books and Journals in Public Opinion, Survey Methods, and Survey Statistics

This article is an update of the April 2010 article. This time we organized the books by topics; this should help the readers to focus on their interests.

It is unlikely to list all new books in the field; we did our best scouting different resources and websites. The list is also focusing only on books published in the English language. Books are listed based on the relevance to the topic and no judgment is made in terms of quality of the content. We let the reader do so.

\section{NEW JOURNALS/JOURNAL NEWS}

International Journal of Internet Science is increasing from 1 to 2 issues a year in 2011. Online only, hosted by the University of Deusto.

International Journal of Social Research Methodology is increasing from 5 to 6 issues a year in 2011. Routledge Publishing.

Methodology: European Journal of Research Methods for the Bebavioral and Social Sciences published a special issue on Survey Experiments. Volume 6, Issue 3, 2010. Hogrefe Publishing.

Floyd J. Fowler, Jr. edited a special selection of articles in survey methodology for public health researchers selecting 18 papers published in Public Opinion Quarterly over the past 20 years. These selected readings are all freely available on the POQ-Oxford website.

Public Opinion Quarterly published a special issue on Total Survey Error. Volume 74, Issue 5, 2010. Oxford Publishing. All papers are freely available on the POQ - Oxford website.

Research Synthesis Methods is a new a multidisciplinary peer reviewed journal sponsored by the Society for Research Synthesis Methodology. Research Synthesis Methods is devoted to the development and dissemination of 
methods for designing, conducting, analyzing, interpreting, reporting, and applying systematic research synthesis. The first issue was published in April 2010 by Wiley.

Sociological Methods $\sigma^{2}$ Research (Sage publisher) celebrated its 40th anniversary. Editor Cristopher Winship highlights the major accomplishments of the journal and the top article citation by decade in Volume 40, issue 1, February 2011.

\section{PUBLIC OPINION BOOKS}

Bishop, G. F., \& Mockabee, S. T. (2011). Taking the pulse of public opinion: Leading and misleading indicators of the state of the nation. Springer.

Charnin, R. (2010). Proving election fraud: Phantom voters, uncounted votes, and the National Exit Poll. Bloomington, IN: AuthorHouse.

Clawson, R. A., \& Oxley, Z. M. (2010). Conducting empirical analysis: Public opinion in action. Washington DC : CQ Press College.

Erikson, R. S., \& Tedin, K. L. (2011). American public opinion: Its origins, content, and impact (8th ed.). Longman.

Gallup, A. M. (2010). The Gallup Poll: Public opinion 2009. Lanham, MD: Rowman \& Littlefield.

Goidel, K. (Ed.). (2011). Political polling in the digital age: The challenge of measuring and understanding public opinion. Baton Rouge, LA: Louisiana State University Press.

Simon, A. F. (2011). Mass informed consent: Evidence on upgrading democracy with polls and new media. Plymouth, UK: Rowman \& Littlefield.

Wilson, F. (2011). A theory of public opinion. A reprint of a classic book with a new introduction by $H$. Lee Cheek, Jr. Edison, NJ: Transaction Publisher.

Yankelovich, D., \& Friedman, W. (Eds.). (2011). Toward wiser public judgment. Nashville, TN: Vanderbilt University Press.

\section{SURVEY METHODS BOOKS}

Bethlehem, J., Cobben, F., \& Schouten, B. (2011). Handbook of nonresponse in bousebold surveys. Hoboken, NJ: Wiley.

Brown, L. D., Cohen, M. L., Cork, D. L., \& Citro, C. F. (Eds.). (2010). Envisioning the 2020 Census. Washington, D.C. The National Academies Press.

Bulmer, M., Gibbs, J., \& Hyman, L. (Eds.). (2010). Social measurement through social surveys. An applied approach. Farnhan, Surrey: Ashgate.

Chaudhuri, A. (2010). Randomized response and indirect questioning 
techniques in surveys. Boca Raton, FL: Chapman and Hall/CRC.

Cooper, B., \& Philips, M. (2010). Custom surveys within your budget: Maximizing profits through effective online research design. Ithacha, NY: Paramount Market.

Das, M., Ester, P., \& Kaczmirek, L. (Eds.). (2010). Social and behavioral research and the Internet: Advances in applied methods and research strategies. New York: Routledge.

Davidov, E., Schmidt, P., \& Billiet, J. (Eds.). (2010). Cross-cultural analysis: Methods and applications. New York: Routledge.

Gaquin, D. A. (Ed.). (2010). The who, what, and where of America: Understanding the American Community Survey. Lanhan, MD: Bernan Press.

Hauser, R. M., Weinstein, M., Pool, R., \& Choen, B. (Eds.). (2010). Conducting biosocial surveys: Collecting, storing, accessing, and protecting biospecimens and biodata. Washington, D.C. The National Academies Press.

Heise, D. R. (2010). Surveying cultures: Discovering shared conceptions and sentiments. Hoboken NJ: Wiley.

Marton, K., \& Voss, P. R. (Eds.). (2010). Measuring the group quarters population in the American Community Survey: interim report. Washington, D.C. The National Academies Press.

Plewes, T. J. (Ed.). (2010). Protecting and accessing data from the survey of earned doctorates: A workshop summary. Washington, DC: The National Academies Press.

Poynter, R. (2010). The handbook of online and social media research: Tools and techniques for market researchers. Chicester: Wiley.

\section{SURVEY STATISTICS BOOKS}

Biemer, P. P. (2011). Latent class analysis of survey error. Hoboken, NJ: Wiley. Hussain, Z. (2011). Randomized response models in survey sampling. Randomized response models. VDM Verlag Dr. Müller.

Enders, C. K. (2010). Applied missing data analysis. New York: Guilford.

Pfeffermann, D., \& Rao, C. R. (2011). Essential methods for design based sample surveys. Amsterdam: North Holland.

Shoukri, M. M. (2010). Measures of interobserver agreement and reliability. Boca Raton, FL: CRC Press.

Waal, T. de, Pannekoek, J., \& Scholtus, S. (2011). Handbook of statistical data editing and imputation. Hoboken, NJ: Wiley. 


\section{CALL FOR SPECIAL ISSUES}

Public Opinion Quarterly: special issue on Measurement. Deadline December 31, 2011. Link to official call for papers.

ANNOUNCEMENT AND CALL FOR MANUSCRIPTS FOR THE SPECIAL EDITION 40 YEARS OF THE SPIRAL OF SILENCE

It was in 1972 when Elisabeth Noelle-Neumann first outlined the main features of the theory of the spiral of silence at the International Congress of Psychology in Tokyo. Forty years later, in the year 2012, the International Journal of Public Opinion Research is planning to publish a special edition of the Journal focusing on the theory. Guest editor is Dr. Thomas Petersen.

What significance did the spiral of silence theory have for the social sciences in the past and what is its significance today? How did the theory influence the development of the field? Which elements of the theory have been empirically confirmed and which have not? Does the theory continue to be relevant today or are there elements that are either outdated from today's perspective or which need to be developed or investigated further? These are just some of the questions that could be addressed in the planned special edition.

Researchers from around the world who deal with the spiral of silence are thus cordially invited to submit articles, including both theoretical discussions and papers focusing on empirical studies. Please submit your manuscript to the IJPOR website at http://mc.manuscriptcentral.com/ijpor - and remember to mark your manuscript as being intended for the "Special Edition Spiral of Silence.” The deadline is September 1, 2011. 